Carsin, A.E., Zock, J.P., Jarvis, D., Basagaña, X., Heinrich, J., Torén, K., Janson, C., Antó, J.M. Sunyer, J. Serum total immunoglobulin $\mathrm{E}$ is a surrogate of atopy in adult-onset asthma: a

\begin{tabular}{|l|l|}
\hline $\begin{array}{l}\text { Postprint } \\
\text { Version }\end{array}$ & 1.0 \\
\hline Journal website & http://www.karger.com/Article/FullText/342464 \\
\hline Pubmed link & $\underline{\text { http://www.ncbi.nlm.nih.gov/pubmed/23183370 }}$ \\
\hline DOI & $10.1159 / 000342464$ \\
\hline
\end{tabular}

This is a NIVEL certified Post Print, more info at http://www.nivel.eu

\title{
Serum Total Immunoglobulin E Is a Surrogate of Atopy in Adult-Onset Asthma: A Longitudinal Study
}

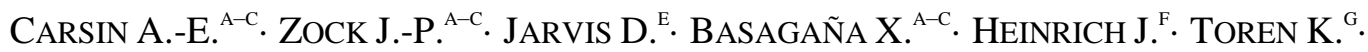 \\ JANSON C. ${ }^{\mathrm{H}} \cdot$ ANTO J.M. ${ }^{A-D} \cdot$ SUNYER J. ${ }^{A-D}$
}

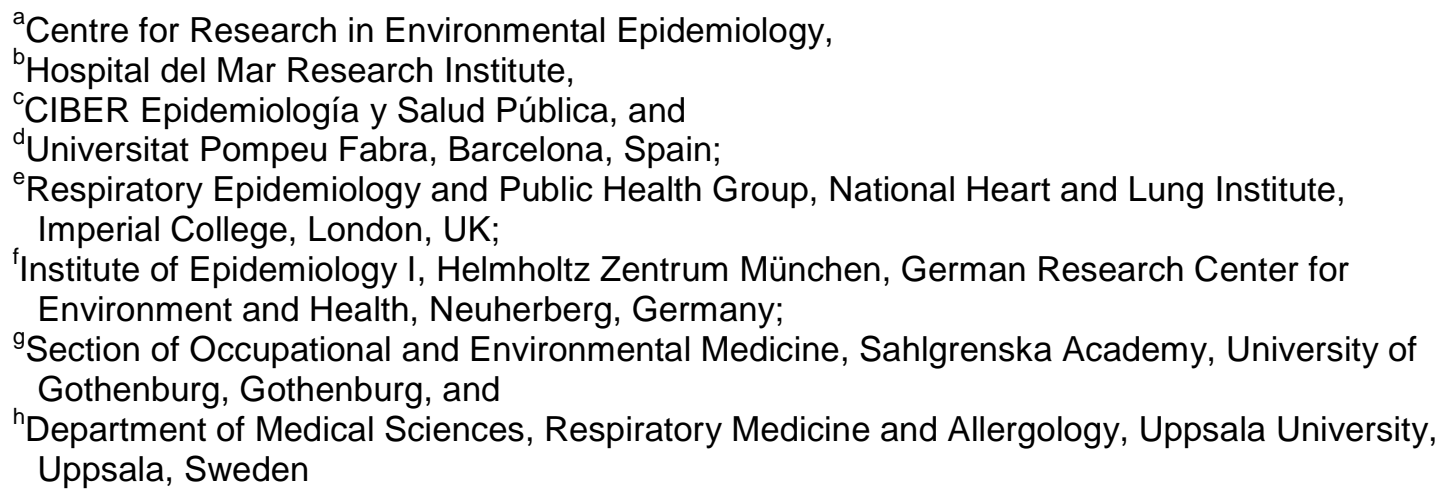

\begin{abstract}
Background: Studies have shown that serum total immunoglobulin E (IgE) levels are higher in asthmatics. However, the role of the serum total IgE level, independently from atopy, in adult asthma is not understood. We studied the associations between serum total IgE, the number of sensitizations and the sum of specific IgEs and new-onset asthma using longitudinal data from the European Community Respiratory Health Survey. Methods: Serum total and specific IgE to 4 common inhalant allergens were measured at baseline in 9,175 participants, with a follow-up of 9 years. Individuals with asthma history and/or asthma symptoms were excluded. Atopy was defined as the presence of at least one specific $\operatorname{IgE} \geq 0.35 \mathrm{kU} / 1$. Total and specific IgEs were regressed against new-onset asthma using multivariate logistic regression with a random intercept for the study centre. Results: Two hundred and ninety-seven participants had developed asthma during follow-up (incidence rate 5.7 per 1,000 person-years). A $10 \%$ higher level of total IgE was associated with a $12 \%$ increased risk of new-onset asthma $(p=0.005)$. However, after adjustment for the number of positive specific IgEs [odds ratio (OR) for multiple sensitization 1.74, 95\%
\end{abstract}


Carsin, A.E., Zock, J.P., Jarvis, D., Basagaña, X., Heinrich, J., Torén, K., Janson, C., Antó, J.M. Sunyer, J. Serum total immunoglobulin $\mathrm{E}$ is a surrogate of atopy in adult-onset asthma: a longitudinal study. International Archives of Allergy and Immunology: 2013, 160(4), 387-392

confidence interval (CI) 1.05-2.88] and the sum of allergen-specific IgEs (OR 1.18, 95\% CI 1.00-1.40), the association between total IgE and asthma disappeared (OR 1.00, 95\% CI 0.91-1.10). Seventeen percent of new-onset asthma cases could be attributed to atopy, and this estimate was not largely modified when the total IgE level was simultaneously taken into account. Conclusions: After taking into account the number and intensity of 4 specific IgEs, the serum total IgE level was not associated with new-onset asthma in adults.

\section{INTRODUCTION}

The role of atopy in adult asthma is uncertain. In Europe, the proportion of newonset asthma in adults due to atopy was estimated to range between 12 and $21 \%\left[{ }^{1}\right]$, less than in childhood asthma (between 25 to $65 \%$ ) [ [ $\left.{ }^{3}\right]$. However, these studies were based on measures of specific immunoglobulin $\mathrm{E}$ (IgE) or prick tests, which could have underestimated the role of atopy. An alternative biomarker of atopy is total IgE. The total IgE level reflects both specific IgE (directly related to atopy) and unspecific IgE $\left[{ }^{4}\right]$. Many previous studies reported an independent effect of total IgE on asthma $\left[{ }^{5},{ }^{6},{ }^{8}\right]$. This association could be due to the non-specific part of total IgE, as in the model suggested by Marsh $\left[{ }^{9},{ }^{10}, 11\right]$, which would somehow be related to asthma development, but not only. It has been shown that even non-atopic subjects can react to inhaled environmental particles through an IgE-mediated mechanism $\left[{ }^{12}\right]$. Burrows et al. $\left.{ }^{8}\right]$ was the first to report an association between total IgE and asthma even among non-sensitized individuals using the data from Tucson. Later, Sunyer et al. $\left[{ }^{6}\right]$ reported a similar finding using the European Community Respiratory Health Survey (ECRHS) study. Nonetheless, because those studies were all cross-sectional, it is unclear whether an elevated level of total IgE is an independent risk factor for the development of asthma later in life or whether the latter is rather a consequence of asthma conditions, as already suggested by Burrows et al. $\left[{ }^{8}\right]$. Recently, the longitudinal analysis of ECRHS data in Europe $\left[{ }^{13}\right]$ seems to partially fill this gap and it was reported that total IgE was associated with new-onset asthma, only among atopics. However, in this study, presumably, the definition of atopy had a low sensitivity (defined as any specific $\operatorname{IgE} \geq 0.35 \mathrm{kU} / \mathrm{l}$ ). We aim to clarify the role of total IgE in asthma incidence after removing the potential effect of atopy by using more complete definitions. To our knowledge, no other longitudinal study investigated the role of total IgE, separately from atopy or sensitization. Hence, using longitudinal data from the ECRHS, we investigated the association between the level of serum total IgE and new-onset asthma, controlling for different markers of sensitization and atopic status at baseline.

\section{MATERIALS AND METHODS}

\section{Study Design}

The ECRHS is a multi-centre study involving 29 centres, described elsewhere (full protocol can be found at www.ecrh.org) $\left[{ }^{14}\right]$. Briefly, subjects aged $20-44$ years were randomly selected from the general population to participate in the first study in 1991-1993 (ECRHS I) which involved a detailed questionnaire, blood sample collection and spirometry. Participants were contacted again for a follow-up study between 1999 and 2002. Only those who provided a blood sample at baseline and 
Carsin, A.E., Zock, J.P., Jarvis, D., Basagaña, X., Heinrich, J., Torén, K., Janson, C., Antó, J.M. Sunyer, J. Serum total immunoglobulin $\mathrm{E}$ is a surrogate of atopy in adult-onset asthma: a longitudinal study. International Archives of Allergy and Immunology: 2013, 160(4), 387-39

participated at the follow-up study were analysed in this study $(n=6,165)$. Subjects who had a history of asthma or symptoms (wheezing or whistling without a cold, ever having had asthma and/or having been woken by an attack of shortness of breath in the past 12 months) in ECRHS I $(n=1,702)$ were excluded. Ethical approval was obtained for each centre from the appropriate institutional or regional ethics committee, and written consent was obtained for each participant.

\section{Asthma}

New onset of asthma was defined as an affirmative response to either one of these questions 'Have you been woken by an attack of shortness of breath in the last 12 months?', 'Have you had an attack of asthma in the last 12 months?', or 'Are you currently taking any medicines for asthma?' in ECRHS II. In order to check that the results were not influenced by asthma definition, we performed sensitivity analyses, (1) excluding individuals who reported, in ECRHS II, age at first occurrence of asthma before ECRHS I, while not reporting asthma at baseline, and (2) including any individuals who gave a positive answer to 'Have you ever had asthma?' in ECRHS II as asthmatics.

\section{Serum Measurements}

The serum total IgE level and specific IgE levels against Dermatophagoides pteronyssinus, cat dander, timothy grass and Cladosporium were measured by the Pharmacia CAP system $\left[{ }^{15}\right]$. Values were expressed in kU/l. Atopy was defined as any positive specific IgE to at least 1 of the 4 tested allergens $(\geq 0.35 \mathrm{kU} / \mathrm{l})$. The number of positive specific IgEs was also considered. Additionally, we calculated the sum of specific IgE by adding up the 4 specific IgE levels.

\section{Statistical Analysis}

Due to the skewed nature of IgE value distribution, total and specific IgE levels were log-transformed and geometric means were reported.

Associations with new onset of asthma were investigated using multivariate logistic regression analyses with a random intercept for the study centre to account for potential heterogeneity. To assess the role of total IgE, independently from atopy or sensitization, we built a series of models: first, odds ratios (ORs) were estimated separately for each variable of interest (i.e. log total IgE level, number of sensitization, atopy at baseline and sum of specific IgE). Then, the OR for total IgE was adjusted for each of the other variables one by one, and finally, the fully adjusted model was reported. ORs were adjusted for age, sex, body mass index, smoking status at baseline, pack-year, height and year of follow-up. We further repeated our analysis only among atopics.

Population-attributable risk (PAR) of asthma due to a high total IgE level (>100 $\mathrm{kU} / \mathrm{l}$ ), atopy and number of sensitization and sum of specific IgE was calculated using the estimated OR from the logistic model $\left[{ }^{16}\right]$. Both separate and mutually adjusted risks were reported.

\section{RESULTS}

\section{Study Participants}

Our study was restricted to participants who provided serum samples for total IgE measurements at baseline, leaving 6,165 individuals for analysis. The mean followup time was 8.8 years. The proportion of women was slightly lower among those 
Carsin, A.E., Zock, J.P., Jarvis, D., Basagaña, X., Heinrich, J., Torén, K., Janson, C., Antó, J.M. Sunyer, J. Serum total immunoglobulin $E$ is a surrogate of atopy in adult-onset asthma: a longitudinal study, International Archives of Allergy and Immunology: 2013, 160(4), 387-39

included in the final analysis in comparison to all participants taking part in both surveys (51 vs. $60 \%$; $\mathrm{p}<0.001$ ). The total IgE level at baseline was similar in the two groups (participants/excluded), and no other difference was observed.

\section{Serum Total IgE at Baseline and Individual Characteristics}

The overall geometric mean of total IgE concentration at baseline was $26.4 \mathrm{kU} / \mathrm{l}$ [95\% confidence interval (CI) 25.4-27.5].

As shown in previous publications $\left[{ }^{17}\right]$, men and current smokers had significantly higher levels of total IgE at baseline (online suppl. table 1; for all online suppl. material, see www.karger.com/doi/10.1159/000342464). The association with smoking depended on intensity, with heavier smokers having the highest total IgE levels.

Individual characteristics by atopy are presented in table ${ }^{1}$. Those with atopy were significantly more likely to be younger, males and non-smokers. The incidence of asthma was twice as high among those with atopy when compared to the others (4 vs. $7 \%$ ). Among those with atopy, 35\% had multiple sensitizations. The geometric mean of the sum of specific IgE was much lower than the level of total IgE. The two variables were correlated $(r=0.42)$ but not collinear.

\section{[TABEL 1]}

There was no major difference in lung function at baseline or after follow-up by atopy.

\section{Serum Total IgE and New-Onset Asthma}

During the follow-up, 297 (4.9\%) individuals developed asthma.

A higher baseline total IgE level was associated with a higher risk of new-onset asthma (table ${ }^{2}$, model No. 2; OR 1.12, 95\% CI 1.04-1.21). The association was only apparent among atopic subjects (p value for interaction 0.07). Thus, an individual with a baseline total IgE level of $196 \mathrm{kU} / \mathrm{l}$ (corresponding approximately to the 75th percentile of the distribution among atopics) had a 22\% increase in the risk of developing asthma compared to an individual with a baseline level of $31 \mathrm{kU} / \mathrm{l}$ (25th percentile). No association between serum total IgE and new-onset asthma was observed among those individuals without atopy at baseline (OR 0.98, 95\% CI 0.881.09).

\section{[TABLE 2]}

Multiple sensitization and the sum of specific IgE were associated with new-onset asthma, overall and among atopic subjects. Subsequently, adjusting for multiple sensitization and the sum of specific IgE weakened the association with total IgE toward nullity (table ${ }^{2}$ ).

The proportion of new-onset asthma attributable to atopy was estimated to be $16.9 \%$ (fig. ${ }^{1}$ ). It was distributed as follows: $7.7 \%$ for having multiple sensitizations and $5.8 \%$ for having a sum of specific IgE level $>4 \mathrm{kU} / \mathrm{l}$. Only $2.8 \%$ of new-onset asthma was due to a level of total IgE $>100 \mathrm{kU} / \mathrm{l}$ after taking into account other markers of atopy. 
Carsin, A.E., Zock, J.P., Jarvis, D., Basagaña, X., Heinrich, J., Torén, K., Janson, C., Antó, J.M. Sunyer, J. Serum total immunoglobulin $\mathrm{E}$ is a surrogate of atopy in adult-onset asthma: a longitudinal study. International Archives of Allergy and Immunology: 2013, 160(4), 387-30

[FIGURE 1]

\section{Discussion}

Allergic hypersensitivity is strongly associated with asthma in children $\left[^{2},{ }^{3}\right]$ and was estimated to be related to $25-63 \%$ of childhood asthma $\left[{ }^{1}\right]$. However, the relationship between allergy and asthma in adulthood is weaker $\left[{ }^{18}, 19\right]$. It is believed to contribute less to new-onset asthma cases than in children $\left[{ }^{1}\right]$. Furthermore, the role of serum total IgE, often used as a surrogate for atopy, had not been previously investigated independently from serum-specific IgE. In this context, our study demonstrates two new findings: (1) total IgE is related to new-onset asthma, but this association is almost entirely explained by specific IgE, and (2) only $17 \%$ of new-onset asthma in adults could be attributed to multiple sensitization and higher levels of specific IgE. Our findings differ from the results of previous cross-sectional studies which have reported an association between the level of total IgE and asthma $\left[{ }^{5},{ }^{6}\right]$. Interestingly, it means that elevation of total IgE in asthmatics is likely to occur simultaneously or, at least, during a time window close to asthma occurrence. Burrows et al. $\left.{ }^{[19}\right]$ suggested that elevated total IgE was a consequence of asthma, rather than a marker for development. For instance, serum levels would possibly rise due to inflammation. Only few longitudinal studies investigated this $\left[{ }^{13}, 20,21,22,23\right]$, and most of those were limited in size or did not investigate the effect of total IgE independently from atopic status. Using the ECRHS data, a significant association between new-onset asthma and total IgE was found by Anto et al. $\left[{ }^{13}\right]$. Using the same cohort of individuals, we have now clarified that most of the relationship was due to atopy and not to total IgE per se. Previous studies may not have modelled the joint presence of total and specific IgE enough to estimate their independent roles.

Several other causes might explain the majority (83\%) of new-onset asthma, which are not attributed to atopy, such as respiratory infection, chemical irritants (cleaning products), occupational exposure, pollution, and others $\left[{ }^{24},{ }^{25}, 26\right]$.

This is a large multi-centre study, with a large amount of data, and therefore, with large statistical power. The longitudinal design allowed us to look at the time-toevent casual pathways.

To avoid potential selection bias, we excluded from our sample any individual with respiratory symptoms at baseline using a wide range of respiratory-related questions available in the baseline questionnaire. In addition, we performed sensitivity analyses, using a stricter and broader definition of asthma, with very similar associations.

A strength of this study is the consistency in the sensitivity analysis after defining atopy in different ways. In addition to the classic definition of atopy using a cut-off of the specific IgE level, we computed the sum of the specific IgE level to reduce misclassification, in accordance with the model proposed by Marsh et al. $\left[{ }^{9}\right]$. Atopy was assessed using only four allergens measured via specific IgE levels. However, studies have shown that only few allergens are necessary to detect atopy in the majority of individuals $\left[{ }^{27}\right]$. Misclassification of truly atopic individuals into the nonatopic group would result in a residual association between total IgE and asthma. This was not observed in our study, suggesting that bias did not occur. A limitation is that we have not assessed the role of bronchial hyperresponsiveness which could present more likely in asymptomatic people with atopy than in non-atopics; thus, 
Carsin, A.E., Zock, J.P., Jarvis, D., Basagaña, X., Heinrich, J., Torén, K., Janson, C., Antó, J.M. Sunyer, J. Serum total immunoglobulin $\mathrm{E}$ is a surrogate of atopy in adult-onset asthma: a Iongitudinal study. International Archives of Allergy and Immunology: 2013, 160(4), 387-392

some people with high total IgE and no specific IgE may have bronchial hyperresponsiveness but no asthma (yet).

To conclude, the serum total IgE level plays a role in later development of asthma. However, association was nearly entirely explained by specific IgE level, number of sensitization and atopy. Overall, the amount of asthma attributable to atopy among adults appears to be much lower than in the children.

\section{Acknowledgements}

Jan-Paul Zock, Deborah Jarvis, Heinrich Joachim, Kjell Toren, Christer Janson, Josep Maria Anto, and Jordi Sunyer are members of the steering committee of the ECRHS II. The coordination of ECRHS II was supported by the European Commission, as part of their Quality of Life Programme. For detailed lists of funding bodies and principal investigators, see online supplementary material.

\section{Disclosure Statement}

We declare that we have no conflicts of interest. 
Carsin, A.E., Zock, J.P., Jarvis, D., Basagaña, X., Heinrich, J., Torén, K., Janson, C., Antó, J.M. Sunyer, J. Serum total immunoglobulin E is a surrogate of atopy in adult-onset asthma: a longitudinal study. International Archives of Allergy and Immunology: 2013, 160(4), 387-30

\section{REFERENCES}

Pearce N, Pekkanen J, Beasley R: How much asthma is really attributable to atopy? Thorax 1999;54:268-272.

Sears MR, Burrows B, Flannery EM, Herbison GP, Hewitt CJ, Holdaway MD: Relation between airway responsiveness and serum IgE in children with asthma and in apparently normal children. N Engl J Med 1991;325:1067-1071.

Schäfer T, Wölke G, Ring J, Wichmann HE, Heinrich J: Allergic sensitization to cat in childhood as major predictor of incident respiratory allergy in young adults. Allergy 2007;62:1282-1287.

Jackola DR, Blumenthal MN, Rosenberg A: Evidence for two independent distributions of serum immunoglobulin $E$ in atopic families: cognate and non-cognate IgE. Hum Immunol 2004;65:20-30.

Beeh KM, Ksoll M, Buhl R: Elevation of total serum immunoglobulin E is associated with asthma in nonallergic individuals. Eur Respir J 2000;16:609-614.

Sunyer J, Antó JM, Castellsagué J, Soriano JB, Roca J: Total serum IgE is associated with asthma independently of specific IgE levels. The Spanish Group of the European Study of Asthma. Eur Respir J 1996;9:1880-1884.

Gergen PJ, Arbes SJ, Calatroni A, Mitchell HE, Zeldin DC: Total IgE levels and asthma prevalence in the US population: results from the National Health and Nutrition Examination Survey 2005-2006. J Allergy Clin Immunol 2009;124:447-453.

Burrows B, Martinez FD, Halonen M, Barbee RA, Cline MG: Association of asthma with serum IgE levels and skin-test reactivity to allergens. N Engl J Med 1989;320:271-277.

Marsh DG, Bias WB, Ishizaka K: Genetic control of basal serum immunoglobulin E level and its effect on specific reaginic sensitivity. Proc Natl Acad Sci USA 1974;71:3588-3592.

Marsh DG, Chase GA, Freidhoff LR, Meyers DA, Bias WB: Association of HLA antigens and total serum immunoglobulin $E$ level with allergic response and failure to respond to ragweed allergen Ra3. Proc Natl Acad Sci USA 1979;76:2903-2907.

Marsh DG, Neely JD, Breazeale DR, Ghosh B, Freidhoff LR, Ehrlich-Kautzky E, Schou C, Krishnaswamy G, Beaty TH: Linkage analysis of IL4 and other chromosome 5q31.1 markers and total serum immunoglobulin E concentrations. Science 1994;264:1152-1156. Burney PG, Newson RB, Burrows MS, Wheeler DM: The effects of allergens in outdoor air on both atopic and nonatopic subjects with airway disease. Allergy 2008;63:542-546.

Antó JM, Sunyer J, Basagaña X, Garcia-Esteban R, Cerveri I, de Marco R, et al: Risk factors of new-onset asthma in adults: a population-based international cohort study. Allergy 2010;65:1021-1030.

Burney PGJ, Luczynska C, Chinn S, Jarvis D: The European Community Respiratory Health Survey. Eur Respir J 1994;7:954-960.

Burney P, Malmberg E, Chinn S, Jarvis D, Luczynska C, Lai E: The distribution of total and specific serum IgE in the European Community Respiratory Health Survey. J Allergy Clin Immunol 1997;99:314-322.

Greenland S, Drescher K: Maximum likelihood estimation of the attributable fraction from logistic models. Biometrics 1993;49:865-872.

Jarvis D, Chinn S, Luczynska C, Burney P: The association of smoking with sensitization to common environmental allergens: results from the European Community Respiratory Health Survey. J Allergy Clin Immunol 1999;104:934-940.

Subbarao P, Mandhane PJ, Sears MR: Asthma: epidemiology, etiology and risk factors. CMAJ 2009;181:E181-E190.

Burrows B, Martinez FD, Cline MG, Lebowitz MD: The relationship between parental and children's serum IgE and asthma. Am J Respir Crit Care Med 1995;152:1497-1500.

Sparrow D, O'Connor GT, Basner RC, Rosner B, Weiss ST: Predictors of the new onset of wheezing among middle-aged and older men. The Normative Aging Study. Am Rev Respir Dis 1993;147:367-371.

Bodner CH, Ross S, Little J, Douglas JG, Legge JS, Friend JA, et al: Risk factors for adult onset wheeze: a case control study. Am J Respir Crit Care Med 1998;157:35-42. 
Carsin, A.E., Zock, J.P., Jarvis, D., Basagaña, X., Heinrich, J., Torén, K., Janson, C., Antó, J.M. Sunyer, J. Serum total immunoglobulin $\mathrm{E}$ is a surrogate of atopy in adult-onset asthma: a longitudinal study. International Archives of Allergy and Immunology: 2013, 160(4), 387-30

Jaakkola MS, leromnimon A, Jaakkola JJ: Are atopy and specific IgE to mites and molds important for adult asthma? J Allergy Clin Immunol 2006;117:642-648.

Peat JK, Toelle BG, Dermand J, van den Berg R, Britton WJ, Woolcock AJ: Serum IgE levels, atopy, and asthma in young adults: results from a longitudinal cohort study. Allergy 1996;51:804-810.

Malo JL, L'Archeveque J, Castellanos L, Lavoie K, Ghezzo H, Maghni K: Long-term outcomes of acute irritant-induced asthma. Am J Respir Crit Care Med 2009;179:923-928.

Wang TN, Lin MC, Wu CC, Leung SY, Huang MS, Chuang HY, Lee CH, Wu DC, Ho PS, Ko AM, Chang PY, Ko YC: Risks of exposure to occupational asthmogens in atopic and nonatopic asthma: a case-control study in Taiwan. Am J Respir Crit Care Med 2010;182:1369-1376.

Kogevinas M, Zock JP, Jarvis D, Kromhout H, Lillienberg L, Plana E, Radon K, Toren K, Alliksoo A, Benke G, et al: Exposure to substances in the workplace and new-onset asthma: an international prospective population-based study (ECRHS-II). Lancet 2007;370:336-341.

Bousquet PJ, Hooper R, Kogevinas M, Jarvis D, Burney P: Number of allergens to be tested to assess allergenic sensitization in epidemiologic studies: results of the European Community Respiratory Health Survey I. Clin Exp Allergy 2007;37:780-787.

\section{FIGURES AND TABELS}

Table 1. Individual characteristics by atopy groups at baseline

\begin{tabular}{|c|c|c|c|c|}
\hline Atopy status at baseline ${ }^{1}$ & Total $(n=6,165)$ & Non-atopic $(n=4,526)$ & Atopic $(\mathrm{n}=1,639)$ & p value ${ }^{2}$ \\
\hline Gender & & & & $<0.001$ \\
\hline Male & $3,018(49.0)$ & $2,095(46.3)$ & $923(56.3)$ & \\
\hline Female & $3,147(51.0)$ & $2,431(53.7)$ & $716(43.7)$ & \\
\hline Age, years & $34.2 \pm 7.1$ & $34.6 \pm 7.1$ & $33.2 \pm 7.1$ & $<0.001$ \\
\hline Height, $\mathrm{m}$ & $1.71 \pm 0.09$ & $1.70 \pm 0.10$ & $1.72 \pm 0.09$ & $<0.001$ \\
\hline Smoking status at baseline & & & & $<0.001$ \\
\hline Never & $2,827(46.2)$ & $2,009(44.7)$ & $818(50.3)$ & \\
\hline Ex-smoker & $1,373(22.4)$ & $1,066(23.7)$ & $307(18.9)$ & \\
\hline \multicolumn{5}{|l|}{ Current } \\
\hline$<0.5$ pack per day & $580(9.5)$ & $441(9.8)$ & $139(8.5)$ & \\
\hline $0.5-1$ pack per day & $664(10.8)$ & $489(10.9)$ & $175(10.8)$ & \\
\hline$\geq 1$ pack per day & $678(11.1)$ & $491(10.9)$ & $187(11.5)$ & \\
\hline Body mass index & & & & 0.111 \\
\hline$<25$ (normal) & $4,183(68.8)$ & $3,045(68.2)$ & $1,138(70.5)$ & \\
\hline 25-30 (overweight) & $1,554(25.6)$ & $1,154(25.8)$ & $400(24.8)$ & \\
\hline$>30$ (obese) & $343(5.6)$ & $266(6.0)$ & $77(4.8)$ & \\
\hline New-onset asthma & $297(4.9)$ & $182(4.1)$ & $115(7.1)$ & $<0.001$ \\
\hline Total IgE (GM), kU/l & $26.4 \pm 1.5$ & $17.7 \pm 1.4$ & $79.1 \pm 1.4$ & $<0.001$ \\
\hline Total IgE at follow-up $(\mathrm{GM})^{3}, \mathrm{kU} / \mathrm{l}$ & $33.3 \pm 1.4$ & $24.3 \pm 1.3$ & $80.4 \pm 1.3$ & $<0.001$ \\
\hline Mono-sensitization at baseline & $1,065(17.3)$ & - & $1,065(65.0)$ & - \\
\hline Multiple sensitizations at baseline & $574(9.3)$ & - & $574(35.0)$ & - \\
\hline$\Sigma$ specific IgE (GM) at baseline, $\mathrm{kU} / \mathrm{l}$ & $1.97 \pm 0.88$ & - & $5.47 \pm 1.2$ & \\
\hline Atopy at follow-up ${ }^{3}$ & $1,228(24.8)$ & $255(7.0)$ & $973(74.7)$ & $<0.001$ \\
\hline $\mathrm{FEV}_{1}$ at baseline, $\%$ predicted & $107.0 \pm 12.9$ & $107.2 \pm 12.9$ & $106.5 \pm 13.0$ & 0.087 \\
\hline $\mathrm{FEV}_{1}$ to $\mathrm{FVC}$ ratio at baseline, $\%$ & $83.0 \pm 6.4$ & $83.0 \pm 6.3$ & $83.3 \pm 6.5$ & 0.084 \\
\hline $\mathrm{FEV}_{1}$ decline $^{4}, \mathrm{ml} /$ year & $-28.7 \pm 30.9$ & $-28.6 \pm 30.6$ & $-29.2 \pm 31.6$ & 0.578 \\
\hline
\end{tabular}

Values are means $\pm \mathrm{SD}$; figures in parentheses are percentages. $\mathrm{GM}=\mathrm{Geometric}$ mean; $\mathrm{FEC}_{1}=$ forced expiratory volume in $1 \mathrm{~s}$; $\mathrm{FVC}=$ forced vital capacity.

${ }^{1}$ Atopy defined as any specific IgE $>0.35 \mathrm{kU} / \mathrm{l}$ at baseline. ${ }^{2} \mathrm{p}$ value from $\chi^{2}$ test (categorical), ANOVA or Kruskall-Wallis test (continuous). ${ }^{3} \mathrm{n}=4,954 .{ }^{4} \mathrm{n}=4,874$. 
Carsin, A.E., Zock, J.P., Jarvis, D., Basagaña, X., Heinrich, J., Torén, K., Janson, C., Antó, J.M. Sunyer, J. Serum total immunoglobulin $\mathrm{E}$ is a surrogate of atopy in adult-onset asthma: a longitudinal study. International Archives of Allergy and Immunology: 2013, 160(4), 387-392

Table 2. Associations between specific sensitization and serum total IgE at baseline and the risk of new-onset asthma

\begin{tabular}{|c|c|c|c|}
\hline Model No. & & Total (OR, 95\% CI) & Atopics (OR, 95\% CI) \\
\hline $1 \mathrm{a}$ & atopy & $1.78(1.38-2.29)^{*}$ & - \\
\hline$\overline{1 b}$ & $\begin{array}{l}\text { mono-sensitization } \\
\text { multiple sensitizations }\end{array}$ & $\begin{array}{l}1.40(1.03-1.92)^{*} \\
2.48(1.78-3.45)^{*}\end{array}$ & $\begin{array}{l}1.0 \text { (Ref) } \\
1.76(1.18-2.63)^{*}\end{array}$ \\
\hline $1 \mathrm{c}$ & $\log \Sigma$ specific IgE & $1.34(1.21-1.49)^{*}$ & $1.26(1.08-1.47)^{*}$ \\
\hline 2 & $\log$ total IgE & $1.12(1.04-1.21)^{*}$ & $1.16(1.00-1.34)^{*}$ \\
\hline $3 a$ & $\begin{array}{l}\text { atopy } \\
\text { log total IgE }\end{array}$ & $\begin{array}{l}1.66(1.26-2.21)^{*} \\
1.04(0.96-1.14)\end{array}$ & $\begin{array}{l}- \\
-\end{array}$ \\
\hline $3 \mathrm{~b}$ & $\begin{array}{l}\text { mono-sensitization } \\
\text { multiple sensitizations } \\
\text { log total IgE }\end{array}$ & $\begin{array}{l}1.37(0.98-1.91) \\
2.38(1.63-3.46)^{*} \\
1.02(0.94-1.12)\end{array}$ & $\begin{array}{l}1.0 \text { (Ref) } \\
1.64(1.09-2.48)^{*} \\
1.10(0.95-1.28)\end{array}$ \\
\hline $3 c$ & $\begin{array}{l}\log \sum \text { specific IgE } \\
\log \text { total IgE }\end{array}$ & $\begin{array}{l}1.33(1.17-1.50)^{*} \\
1.02(0.93-1.11)\end{array}$ & $\begin{array}{l}1.23(1.03-1.46)^{*} \\
1.06(0.91-1.25)\end{array}$ \\
\hline 4 & $\begin{array}{l}\text { mono-sensitization } \\
\text { multiple sensitizations } \\
\log \Sigma \text { specific IgE } \\
\log \text { total IgE }\end{array}$ & $\begin{array}{l}1.17(0.80-1.70) \\
1.74(1.05-2.88)^{*} \\
1.18(1.00-1.40)^{*} \\
1.00(0.91-1.10)\end{array}$ & $\begin{array}{l}1.0 \text { (Ref) } \\
1.47(0.95-2.27) \\
1.17(0.97-1.40) \\
1.05(0.89-1.23)\end{array}$ \\
\hline
\end{tabular}

$\mathrm{OR}=$ Odds ratio; $\mathrm{CI}$ = confidence interval; Ref = reference. All models were adjusted for gender, smoking status (current, ex-, nonsmoker), pack-year of smoking, body mass index, \% forced expiratory volume in $1 \mathrm{~s}$ predicted, and time of follow-up. The centre was included in the models as a random effect. ${ }^{*} \mathrm{p}<0.05$.

Fig. 1. PAR of new-onset asthma for each factor separately (black) and mutually adjusted (grey). PAR was derived from models in table 2.

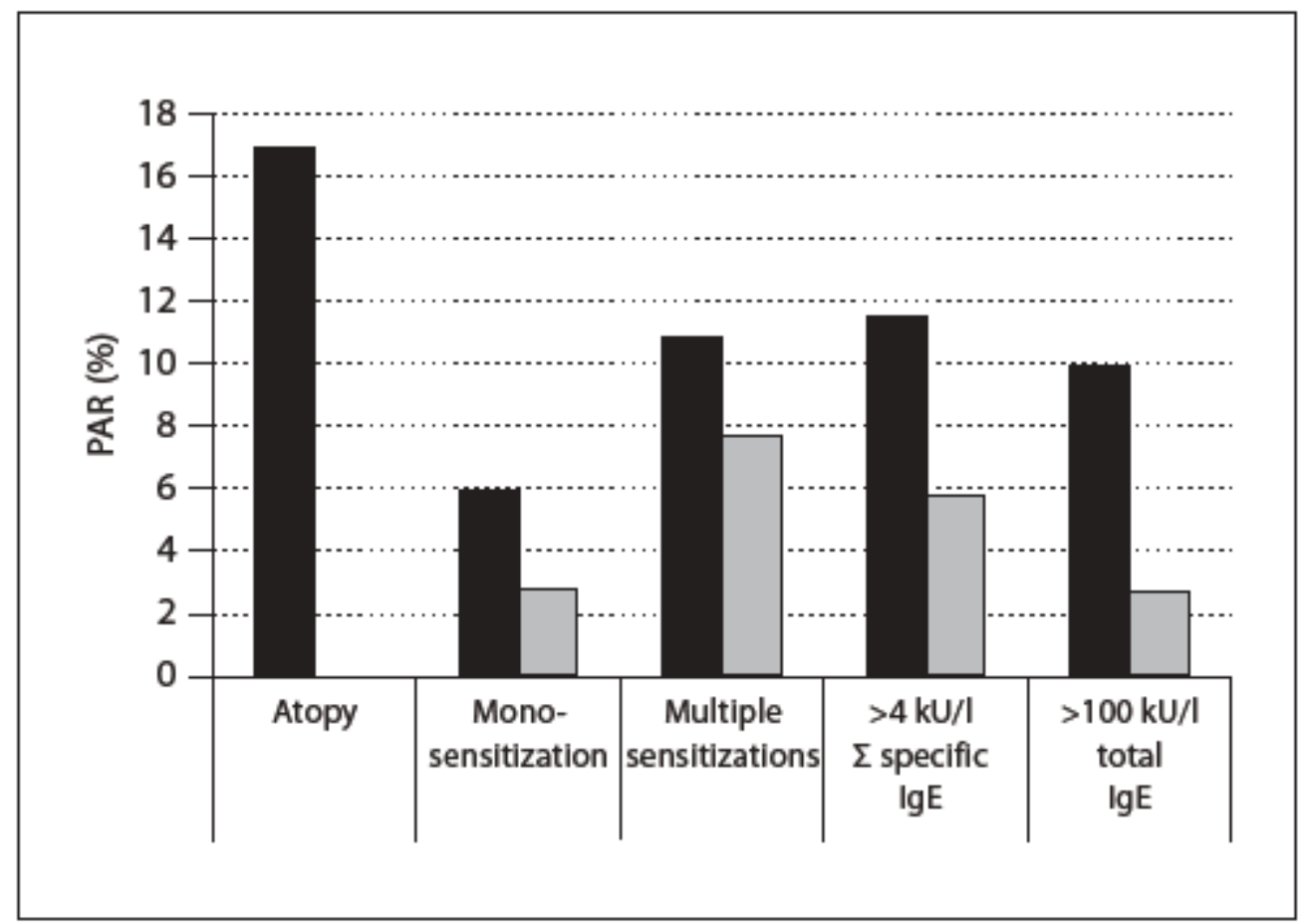

